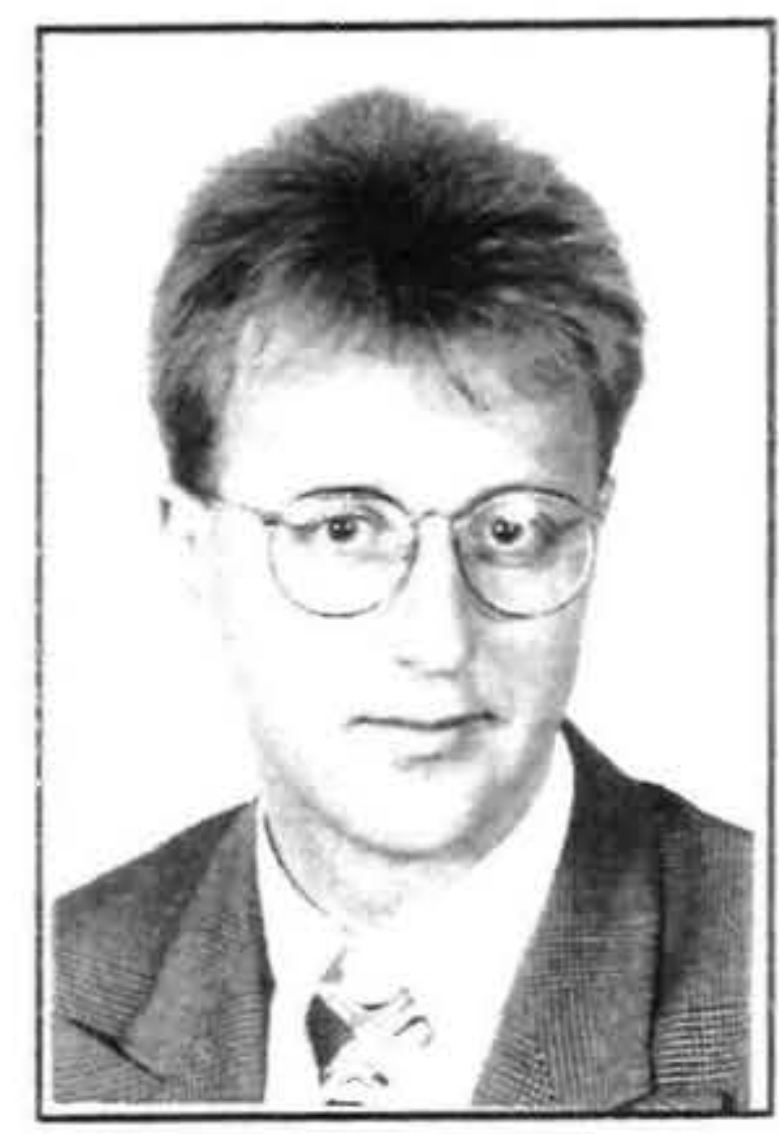

\title{
'NON-STANDARD' WORK IN NEW ZEALAND - WHAT WE KNOW
}

\author{
Richard Whatman
}

Department of Labour

\begin{abstract}
'Non-standard' or 'atypical' work covers a multitude of work arrangements. Definitions of non-standard work are also numerous and rendered partially unsatisfactory by the very nature and variety of the area of study. While non-standard work has been growing in New Zealand, this does not necessarily equate to a worsening situation for all those engaged in non-standard work. This paper suggests definitions of non-standard work arrangements for New Zealand. It discusses the concept of precariousness as it has been applied to the topic and considers what evidence is available to assessit's development. Through this examination, the paper makes suggestions as to wherefurther research in the area of non-standard work could be usefully directed.
\end{abstract}

The range of work place relationships that fall under the ægis of non-standard or atypical work are extensive. Nonstandard work represents relationships that may have more in common in what they are not, rather than what they are. This paper begins therefore by defining non-standard work.

Changes in the incidence of non-standard jobs over the period 1951 to 1994 are examined, and particular emphasis is placed on the 1987-1994 period. There are a number of gaps in the evidence that the Labour Market Analysis Unit (LMA) has assembled; there are difficulties with the data over this period as categorisations and means of collection have changed.

There is a need for more information on the effects of growth in non-standard work on the labour market. There is at present only limited information and this has confined the debate to abstract theoretical frameworks.

\section{Definition of non-standard work}

The increasing proportion of jobs that fall within the umbrella term non-standard calls into question our understanding of fulltime, regular, permanent work.

Our definition of non-standard work begins with the definition of what it is not - standard work is defined as work that meets all the following criteria:

* Fulltime (30 or more hours per week);

* In a permanent job (that is, an expectation of continuing employment);

* Regular hours;

* Over the whole year,
* For someone else; and,

* Primarily at that employer's premises.

Non-standard work includes all those jobs that fall outside this definition of standard employment, for any of the following reasons. That is, they may be:

* Part-time;

* Casual;

* Irregular hours or on-call work;

* Seasonal, temporary or fixed term contracts;

* Self employment;

* Undertaken as 'homework';

* Undertaken in the 'black' economy

* Any combination of the above.

\section{Non-standard work and the concept of 'pre- cariousness'}

Although there are enormous variations in the experience of non-standard workers, they are similar in their difference from standard employees. This is apparent through the treatment that non-standard workers are owed in law. Standard employees carry with them a bundle of legal rights that are more numerous or substantial than for all non-standard workers except for permanent part-time employees with regular hours. Thus, at least in theory, non-standard workers will have a less dense or complex legal relationship with an employer than standard workers. There is also, in relation to all non-standard forms of work (including permanent part-time employees with regular hours) a perception that is sometimes held that they are not at the same level as standard workers.

The distinctions between standard and non-standard work 
have been viewed through a number of theoretical prisms. Themes in the literature identified by Campbell (1994) include 'labour flexibility', 'polarization' (which overlaps with market dualism or segmentation theories) and 'precariousness'. Precariousness is the most recent theme which Campbell (1994) links to the 'contingent worker' and 'casualisation of work' literature.

Rodger and Rodger (1989) construct the concept of precariousness in a European context using several dimensions:

First, there is the degree of certainty of continuing work ... Second there is an aspect of control over work work is more insecure the less the worker (individually or collectively) controls working conditions, wages or the pace of work. Third, protection is of crucial importance: that is, to what extent are workers protected, either by law, or through collective organisation, or through customary practice ... A fourth, somewhat more ambiguous aspect is income - low income jobs may be considered precarious if they are associated with poverty and insecure social insertion. The elements involved are thus multiple: the concept of precariousness involves instability, lack of protection, insecurity and social or economic vulnerability. Not that this eliminates ambiguity; an unstable job is not necessarily precarious. It is some combination of these factors which identifies precarious jobs, and the boundaries around the concept are to some extent arbitrary (Rodger and Rodger (1989), p 5).

The same authors note that:

... the identification of precarious forms of work is by no means straightforward. The simple dichotomy between secure, regular jobs and precarious atypical jobs may be misleading. In practice, an equally important issue may be the security and protection of regular jobs, if these are threatened; and although atypical jobs tend to be more precarious than regular jobs, this is not universally so. Nevertheless...their growth would constitute prima facie evidence that labour market conditions [for workers] have deteriorated, even if there were not still more compelling evidence in the form of persistent high unemployment (Rodger and Rodger (1989), p 6).

Campbell (1994), writing on the Australian experience, argues that the concept of the precariousness of work, or the more antipodean version of it, the casualisation of work “... can provide a useful framework for describing important features of contemporary labour restructuring (though not of course the entire sweep)" (p 8). He argues that casualisation or precariousness increases in three possible ways in relation to the broad division between standard and non-standard work:

... through an increase in the proportion of the workforce in 'precarious' forms of non-standard employment; through an increase in the degree of precariousness within non-standard employment; and through an increase in the degree of precariousness within standard employment (Campbell (1994) p 20).

I have attempted to synthesis the ideas of Campbell (1994) and Rodger and Rodger (1989) in figure 1 below. Precariousness is shown as increasing to the right and downward, which represents a move to non-standard and insecure work. There is, at the heart of the representation, some attempt integrate the ambiguity inherent in the concept, as alluded to by Rodger and Rodger (1989) and Campbell (1994) through the darker ellipse representing those work arrangements that do not conform to type.

New Zealand conditions may well not reflect the situation that these authors discuss in relation to Europe and Australia. More work is needed to determine whether the concept of precariousness is useful in analysing nonstandard employment in this country. In particular, without information on the conditions of the various categories

Figure 1. A proposed matrix of standard and non-standard work and their relationship to precariousness

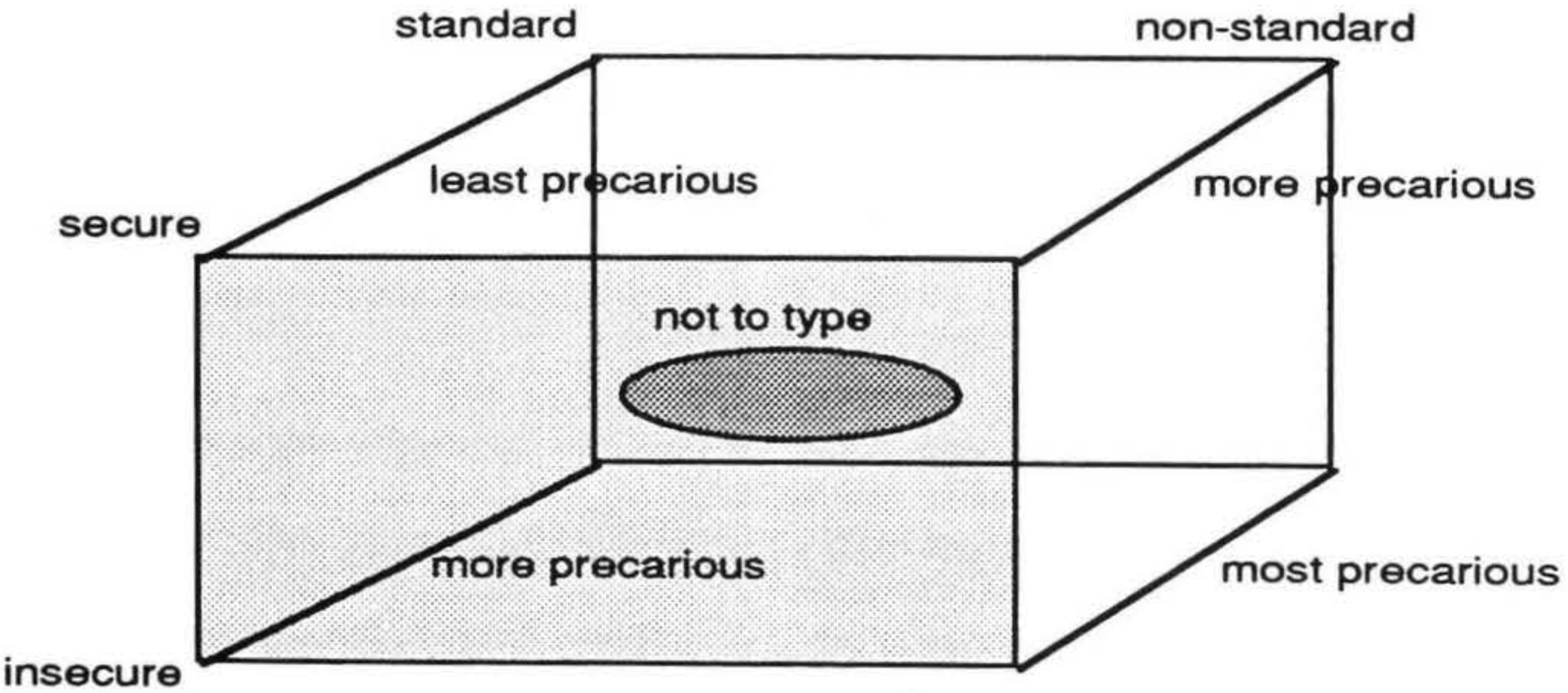


of non-standard as compared with standard employees the concept must remain largely untested. The limitation of data on working conditions is discussed below.

An alternative viewpoint interprets the growth of nonstandard work in positive terms, as an enhancement of the flexibility in hours of work, and working arrangements between workers and employers. Whether the growth in non-standard employment is employer or worker driven may be important in determining the extent to which it results in positive or negative outcomes for workers.

Lewis (1990), for example, discusses whether the increases in part-time work in Australia results from employee or employer demand, and highlights the following finding from a 1985 report:

The Bureau of Labour Market Research has concluded that there is insufficient evidence to determine whether the growth in the part-time labour force reflects responses to supply factors or demand factors, but observes that labour force participation is highly related to opportunities (Lewis, 1990a:54)

In New Zealand there is insufficient evidence to determine the extent to which employer or worker demand is driving the growth in non-standard work. This is important when considering whether precariousness is an appropriate tool for the analysis of non-standard employment because of the assumption in the concept that employers are seeking to increase precariousness and thereby their leverage on conditions of employment.

\section{Information available on non-standard work}

An initial attempt to gather comprehensive information from employers on non-standard work in New Zealand was a 'labour market flexibility survey' conducted in 1991 (Anderson, Brosnan and Walsh, 1992a and b, 1993). The Heylen-Department of Labour Surveys of Labour Market Adjustment conducted in 1992 and 1993 also provide some information on non-standard employment, though this was not the primary purpose of the surveys ${ }^{1}$. There is also some information on temporary and part-time work from an NRB McNair telephone survey conducted for the Department of Labour in April 1989. Other information is available from the Census, the Household Labour Force Survey, the Quarterly Employment Survey and their predecessors. There is some other work, more limited in nature, that has gathered information on particular groups, in particular the self-employed (a number of references are provided for this group at the end of this paper).

The information that is set out below addresses some of the changes to part-time employees in terms of the overall position, gender, industry variations and possible underemployment. It also considers the limited evidence that is available in relation to the working conditions of those in non-standard positions. The statistical information presented concentrates on 1987-94 but with some informa- tion from 1951 through to the 1990s. I have chosen to present this information on part-time employees because it provides the most rounded picture that exists of the changes too, and composition of, a category of non-standard employees. However, because of space limitations only some data is presented. The intention is to show through the use of figures and selected data the broad trends and important characteristics of part-time employment.

In April 1989, NRB McNair conducted a telephone survey for the Department of Labour of 1,000 adults from the general public (over the age of 15), with a 69 per cent response rate. The survey found 45 percent were wage and salary earners, 11 per cent self-employed, 35 per cent not in the workforce and not seeking work, 6 per cent unemployed and seeking work and 3 per cent were classified as 'other'. Of those respondents who were working, the survey categorised them as follows: 78 per cent were fulltime permanent, 5 per cent fulltime temporary, 13 per cent part-time permanent and 4 per cent part-time temporary ${ }^{2}$.

In August and September 1993 2,000 employees were interviewed by telephone by Heylen Research (the 1993 Survey of Labour Market Adjustment) there was a 62 per cent response rate. Those interviewed described themselves as: 76 per cent fulltime permanent employees; 13 per cent permanent part-timers; and 10 per cent casual employees. Employees were asked whether they were a permanent member of staff or employed on a casual basis when required. Where employees described themselves as temporary or short-term contract workers, interviewers were told to code them as casual. However, given the only choice was between permanent or casual, it is unclear how temporary or short-term workers classified themselves. This survey, unlike the Labour Market Flexibility Survey, was only concerned with those in employment.

\section{Part-time employment}

Part-time employment statistics are available over a long time frame. While the Census, Half Yearly Employment Survey (HYES), Quarterly Employment Survey (QES) and the Household Labour Force Survey (HLFS) measures are not strictly comparable, each allow trends to be depicted.

Figure 2 below is drawn from the HYES and the QES. Note that the large change to the employment series in 1988-89 reflect changes to the survey design and should be ignored when looking at the long term changes in the levels of the part-time and fulltime employment.

Until the late 1970s fulltime employment growth exceeded that of part-time employment. From that point, however, part-time employment has continued to expand and at a slightly faster rate, while the expansion of fulltime employment first slowed and was then reversed. Growth in part-time employment also slowed over this period, from 8.16 per cent per annum from 1951 to 1977 , to 3.06 
Figure 2. Fulltime and part-time employment growth, 1951-1992

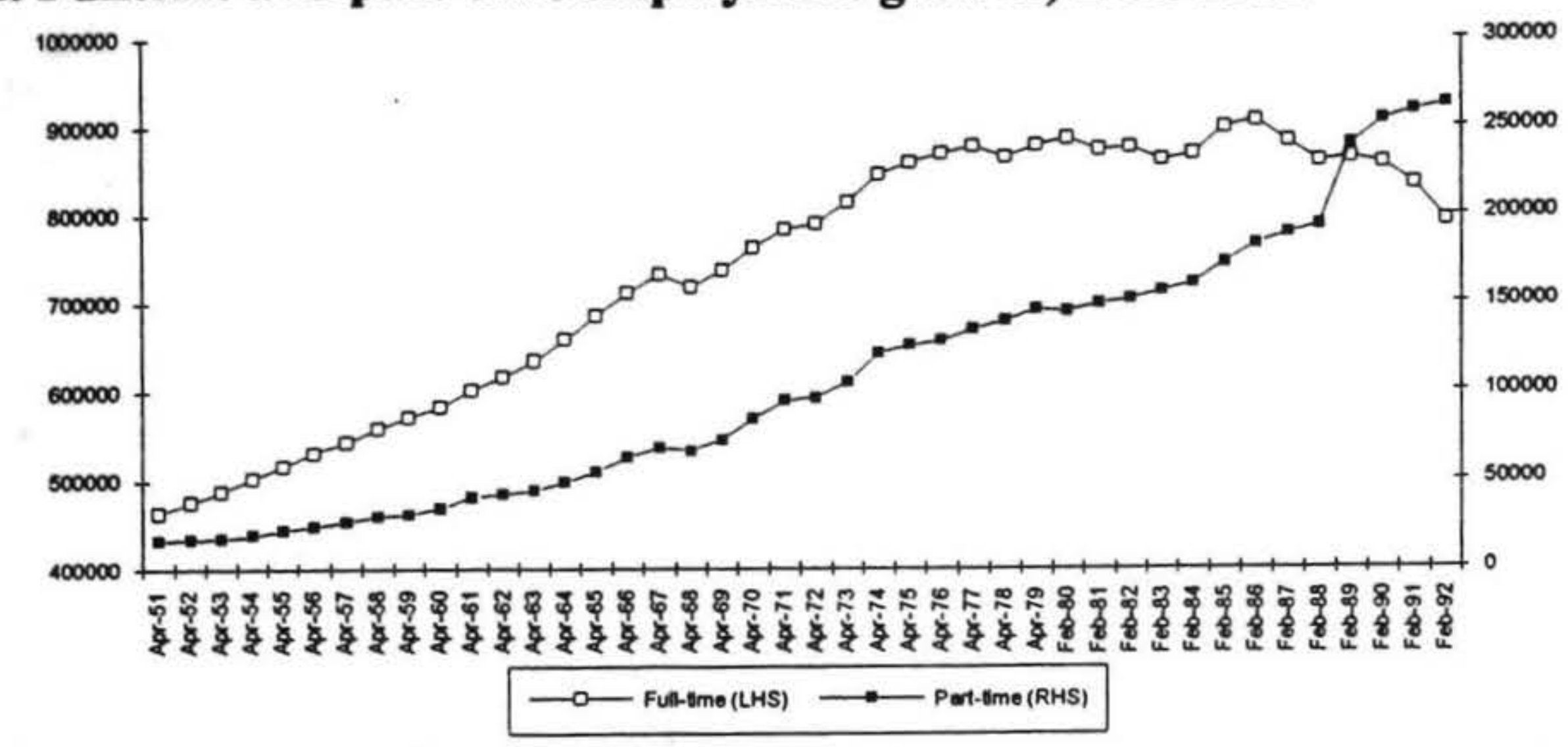

Source: Statistics New Zealand, Half Yearly Employment Survey (HYES) and Quarterly Employment Survey (QES)

per cent from 1977 to 1986 and 2.11 per cent from 1986 to 1992. Of course, the slowing and eventual reversal of fulltime employment growth over this period has meant that the ratio of fulltime to part-time employment has continued to decline.

This 'all industry' picture masks the importance of parttime employment growth in particular sectors of the economy. The strongest growth in part-time employment over this period was in Finance, Insurance and Real Estate with an estimated average annual growth rate of 10.5 per cent over the period 1957-88. Outside of the Finance sector, Community and Personal Services and Retail Trade, Restaurants, and Hotels were the industries with the highest estimated percentage growth rate in part-time employment, at an average of 6.13 and 7.16 per cent per annum from 1957-88. These industries also contain the majority of part-time employees, they are, therefore, largely responsible for the overall increase.

Figure 3 below shows that the estimated number of parttime jobs has been increasing over the past seven years. In contrast, fulltime jobs have displayed a decrease over the corresponding period until recent quarters. Between August 1987 and August 1994 part-time jobs increased by 65.9 per cent, from 261,500 to 393,200 (an annual average increase of 8.8 per cent). During the same period, fulltime jobs decreased by 10.7 per cent, from 1,104,100 to 997,400 (an average annual decrease of 1.4 per cent).

In the February quarter, 1994, the QES estimate of the annual growth rate of part-time employment was 1.8 per cent while fulltime employment was estimated to increase at 3.2 per cent a year, however, in the August quarter the

\section{Figure 3. Full-time and part-time employment growth, 1987-1994 in New Zealand by}

quarter. [Note that the vertical scales for part-time and fulltime employment have different beginning and end points, while the intervals are consistent for both (at 50,000 jobs).]

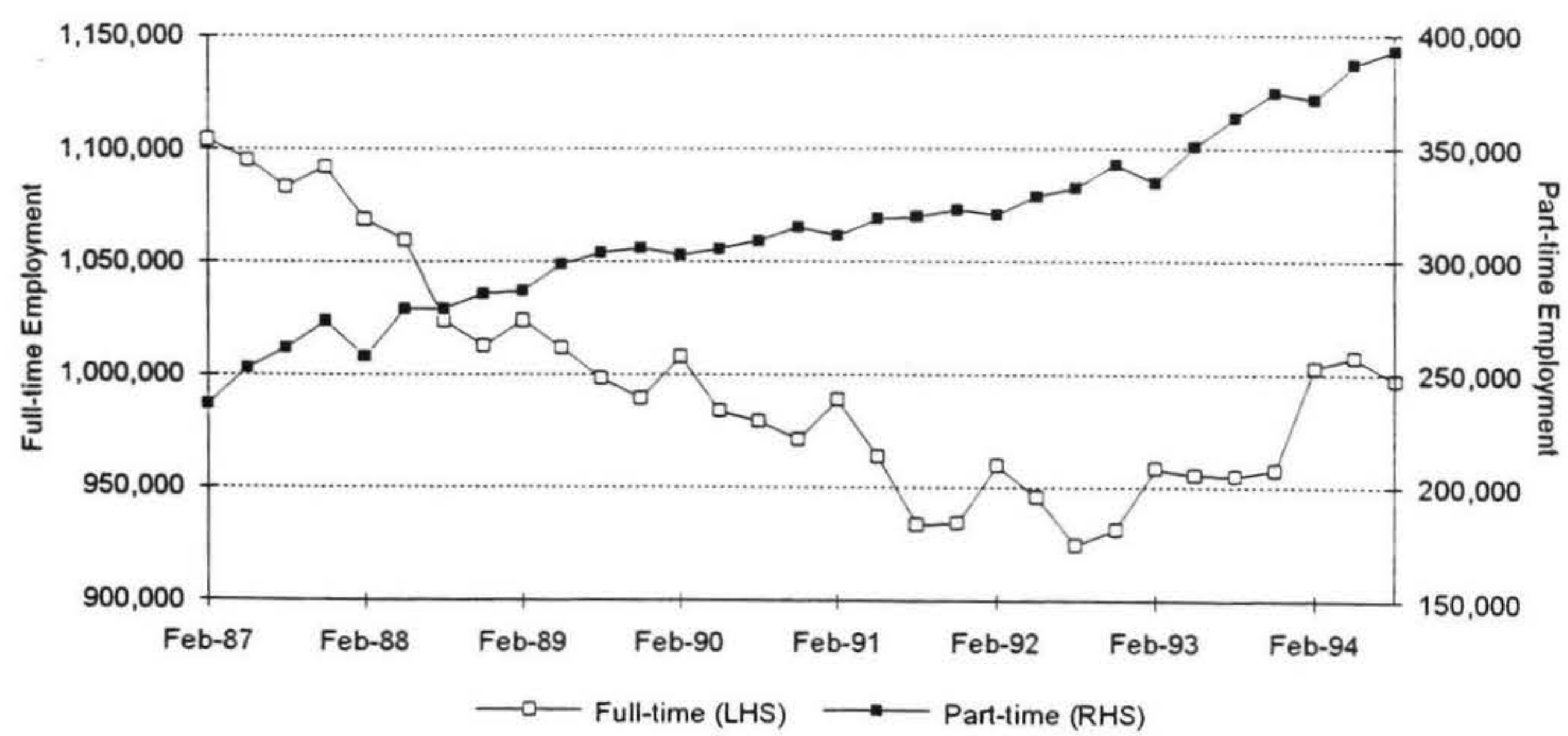

Source: Statistics New Zealand, Half Yearly Employment Survey (HYES) and Quarterly Employment Survey (QES) 
fulltime employment estimate fell by 1 per cent and parttime employment grew by 1.6 per cent. These figures are not seasonally adjusted and also may not reflect the growth in employment that has occurred in the areas that are out of the scope of the QES.

Figure 4 shows that during the period August 1987 to August 1994 the estimate of part-time employees increased as a proportion of all employees measured by the QES, from 19.4 per cent in August 1987 to 28.3 per cent in August 1994. The seasonality of fulltime employment can be seen in the regular peaks and troughs that appear in a yearly cycle.

The NRB McNair (1989) survey found that 92 per cent of the men interviewed reported they were in fulltime permanent employment, compared with 59 per cent of women. Fulltime temporary employment was reported as 4 per cent and 7 per cent for men and women respectively. Part-time permanent employment was reported as 3 per cent and 27 per cent, and part-time temporary employment was reported as 1 per cent and 7 per cent, for men and women respectively.

The 1993 Survey of Labour Market Adjustment reported that 37.4 per cent of the female employees surveyed were non-standard employees, compared to only 11.4 per cent of the male employees. Almost two-thirds of the women in non-standard work were permanent part-time employees. Permanent part-time work accounted for 24.6 per cent of all female employees, with a further 12.7 per cent employed in casual (mostly part-time) work. Male parttime employees were far less likely to be permanent than women (4.2 per cent of male employees) and more likely to be casual part-time employees than women (6.8 per cent of male employees). Male casual employees were evenly split between part-time and fulltime work. The relatively small sample size of this survey means that the male casual worker data, in particular, needs to be treated with caution. QES data indicates a higher proportion of men and women involved in part-time work than this survey indicates (see Figure 5 below).

Figure 5 gives the figures for men and women in part-time employment from the QES, February 1987 to September 1994. The proportion of part-time to total employment as estimated in the QES has increased for men, though declined for women. The proportion of part-time to total jobs declined for women from 50.1 per cent in August 1987 to 42.5 per cent in August 1994, and increased from 8.8 to 16 per cent for men over the same period. In August 1987 the ratio of female to male part-time jobs was 3.5:1, by August 1994 this had declined to 2.3:1. In the period August 1987 to August 1994, the number of part-time jobs held by men increased from 51,700 to 119,400 (an increase of over 130 per cent). In the same period the number of part-time jobs held by women increased from 179,800 to 273,800 (an increase of around 52 per cent).

Figure 6 provides a breakdown of part-time employment by age and sex from the 1986 and 1991 Censi. The patterns that emerge for women are: early participation in part-time employment; then a fall off and steady rise in the level of participation through child bearing years, peaking at 35 ; and from 35 a steady decline in participation. This reflects the importance of child care roles for women, where parttime employment does provide access to employment while allowing for the care of children. For men the pattem is of significant early (15-17 years) and later (greater than 60 years) participation in part-time employment com-

Figure 4. Part-time as a proportion of total employees in New Zealand by quarter, 1987-94

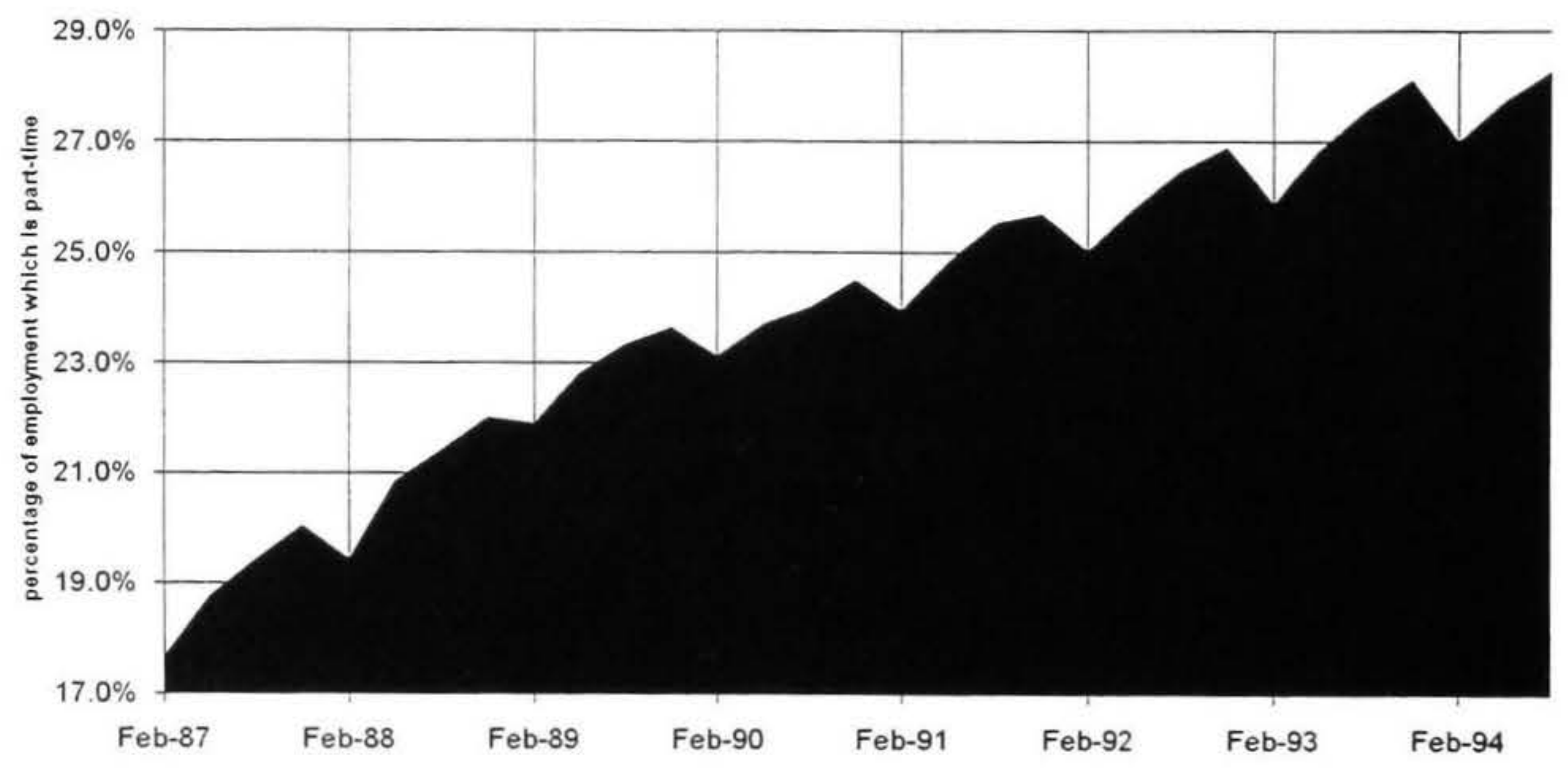

Source: Department of Labour Quarterly Employment Survey 
Figure 5. Part-time employment by gender in New Zealand, 1987-94 [Note that, as with figure 2, the vertical scales have different beginning and end points, while the intervals are consistent (at 20,000 jobs).]

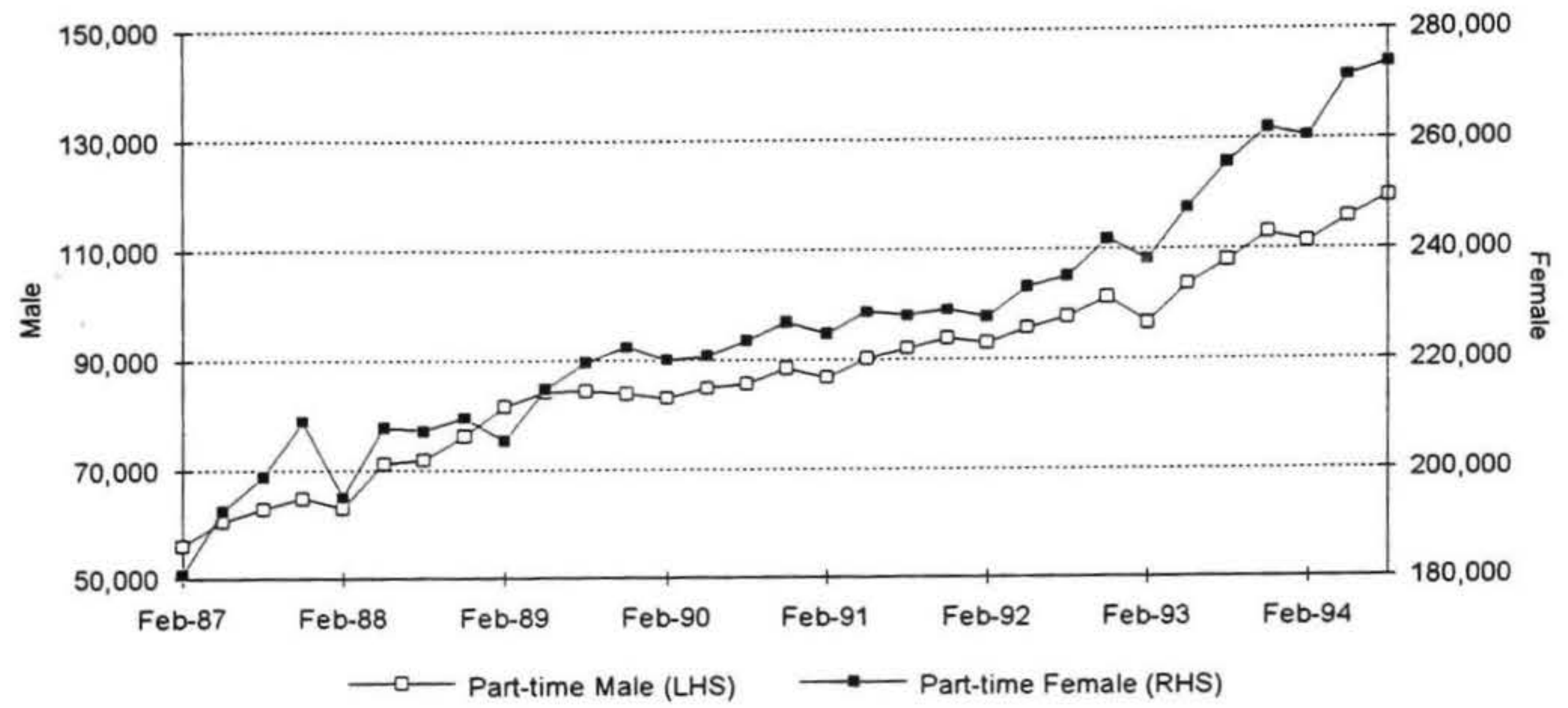

Source: Statistics New Zealand, Quarterly Employment Survey

pared with the years in between these two age cohorts.

\section{Preferences for longer hours}

The term 'under-employment', as used in this paper, refers to employees who either wish to work longer hours or are seeking fulltime employment. The growth in non-standand work may obscure growth in under-employment. Between the September 1987 and 1994 quarters of the HLFS there has been a marked increase in the proportion of both female and male part-time employees who would have like to work longer hours, though there has been some decline for both men and women since the peak in the March 1993 quarter. Over the period, September 1987 to March 1993, the proportion of female part-time employees seeking longer hours increased from 10.6 per cent to 27.6 per cent of all part-time employees, (22,300 to 61,800) whilst the comparable increase for men was even larger, rising from 12.9 per cent to 39.8 per cent $(8,300$ to 31,100$)$. In September 1994 62,500 women and 31,900 men were estimated to have wanted longer hours, that equates to 24.7 per cent of women and 35.5 per cent of men. Figure 7 shows the proportion of part-time employees estimated in the HLFS to desiring more hours of work, between September 1987 and 1994.

A similar but smaller trend was evident in the number of part-time employees seeking fulltime work. Between the years September 1987 and 1994 the number of male parttimers estimated by the HFLS to be seeking fulltime work rose from 3,000 to 11,500 (an increase from 4.7 per cent to 12.8 per cent of all part-time employees). The number of

Figure 6. Part-time employment by age and gender in New Zealand, 1986 and 1991

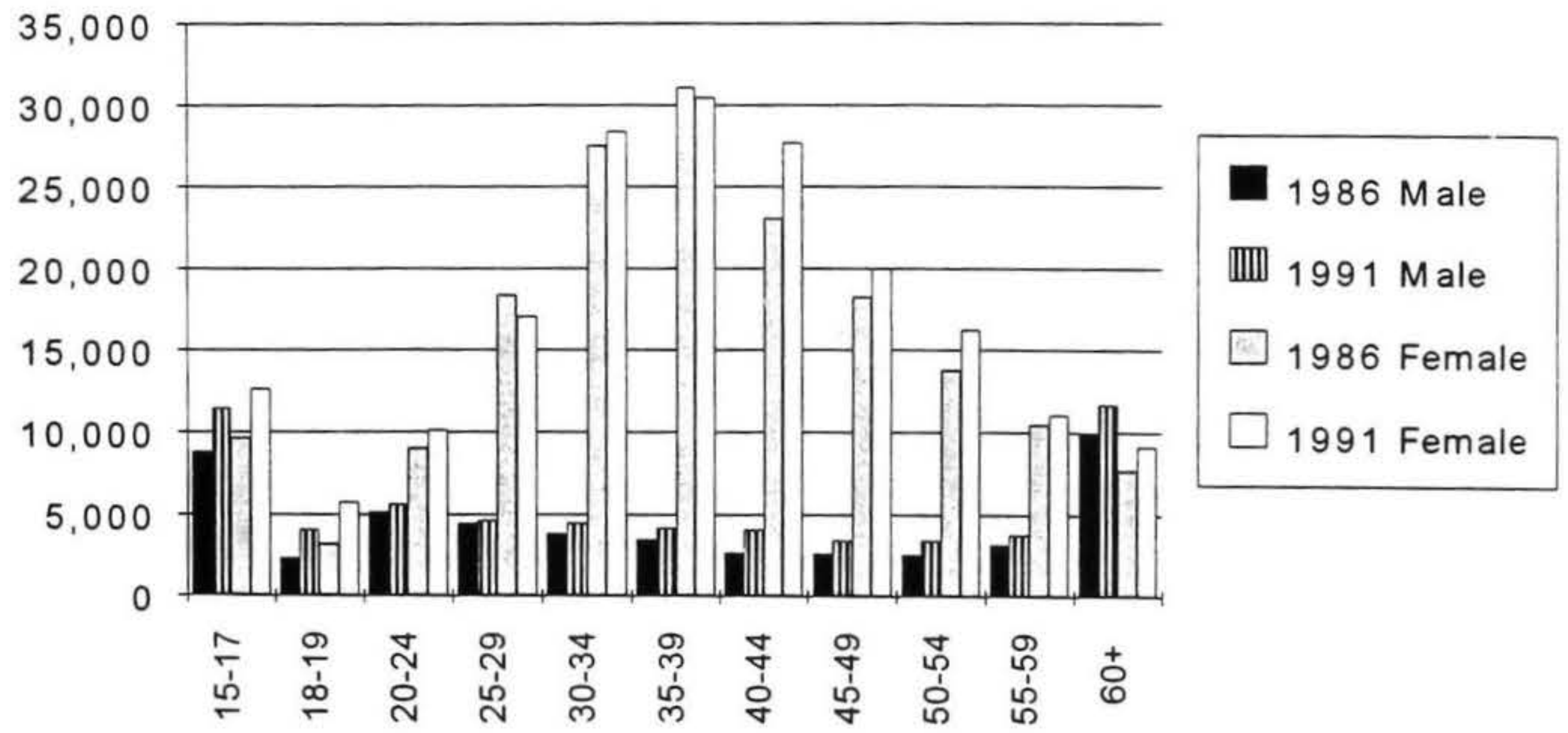

Source: Statistics New Zealand. Census of Population and Dwellings 1986 and 1991 


\section{Figure 7. Proportion of part-timers in New Zealand who would like to work more hours,}

1986-94

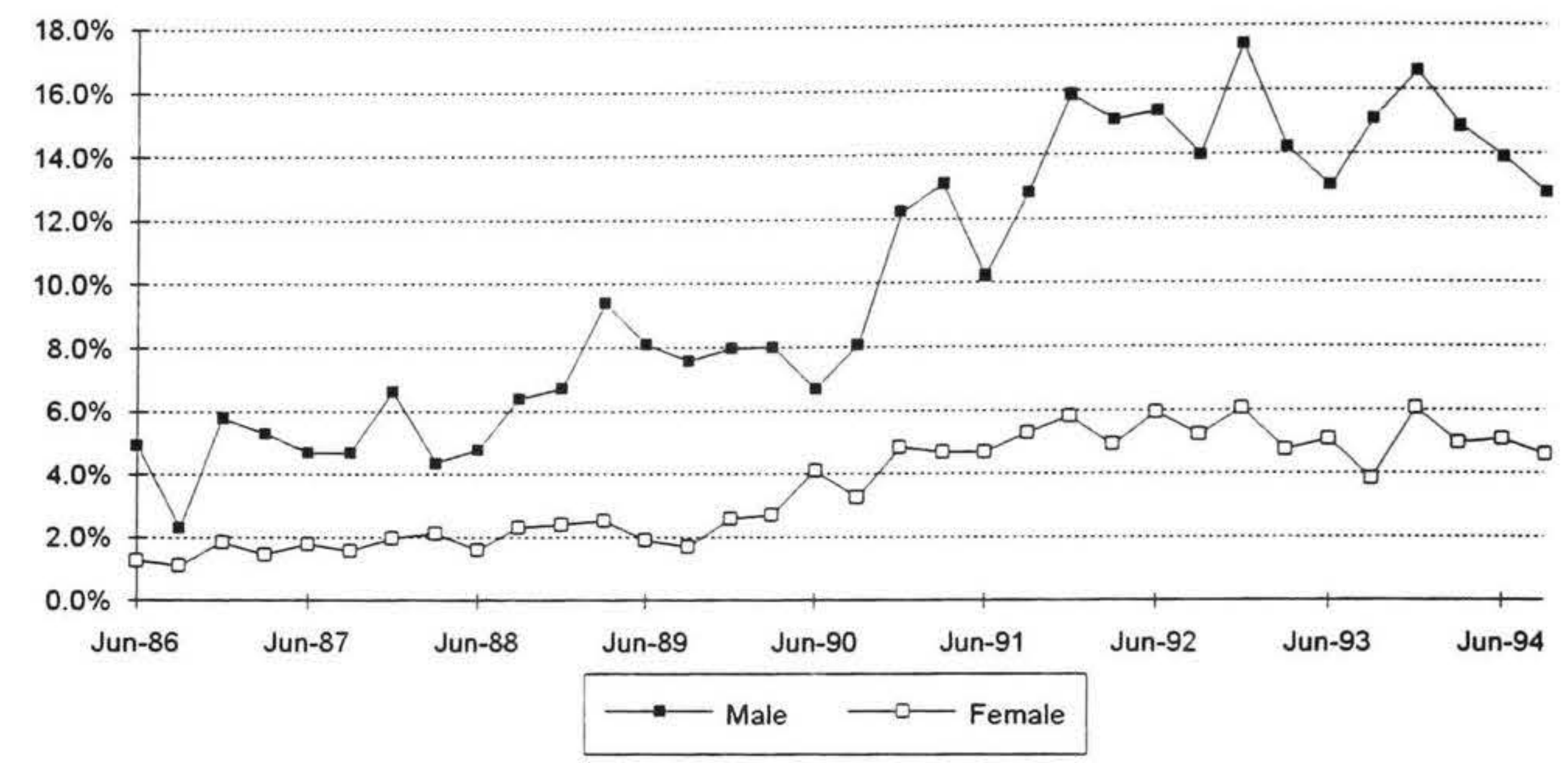

Source: Statistics New Zealand, Household Labour Force Survey

women part-timers seeking fulltime work rose from 3,300 to 11,600 (an increase from 2.3 per cent to 4.6 per cent of all part-time employees). This may be a reflection of both increasing independence amongst women and the decline in male employment encouraging women whose partners lost their jobs to seek fulltime employment.

\section{Self employment}

The Census provides the longest available time series on the self-employed. ${ }^{4}$ The percentages drawn from Census data of all those who are self-employed but not employing others as a proportion of all those in employment, from 1951-91, show a consistent fall and rise from 20 per cent in 1951 to 13 per cent in 1971 and then 20 per cent again in 1991 (Haines, 1991). ${ }^{5}$ This reflects both an absolute growth in the numbers of self-employed and a decline in the numbers of wage and salary eamers in the late 1980s. While there are also figures for self-employed that include employers, the more likely source of non-standard and precarious work lies with those self-employed who do not employ others.

\section{Gender differences}

The numbers of self-employed women have grown greatly over the period 1951-91. As a proportion of the female workforce since 1961, the expansion of the self-employed is even more rapid than for women's employment as a whole. The number of women self-employed and not employing others have risen from 7,683 in 1951 to 43,125 in 1991, while for men the figures are 71,235 and 116,268. For men the most significant occupational groups of selfemployed are in Agriculture and Forestry and Production, Transport and Labourers. For women Agriculture was also significant, with Sales being the next most significant.
The rise in the level of self-employment over the 1980s may also be an indication of under-employment, though there is no information on the degree of choice that was available for those who became self-employed.

\section{Industry variation}

Aggregate figures disguise significant variation between industries. Figure 8 compares the ratio of part-time jobs to total jobs by industry in August 1987 with that in August 1994. It shows that the proportion of part-time jobs increased for all industries between 1987 and 1994.

\section{Working conditions}

The 1993 Survey of Labour Market Adjustment provides some information on the relative working conditions of casual as opposed to permanent, and part-time as opposed to fulltime employees. Analysis of cross-tabulations strongly suggests that part-time or casual employees are less likely than those in fulltime or permanent employment to have access to a wide range of employment conditions and/or they mistakenly believe they do not have access to these conditions (Ryan, 1994). These tables include people who answered either 'never had' or 'not applicable' when asked about changes to specific employment conditions between September 1992 and August/September 1993. The double-barrelled nature of this response makes it impossible to determine whether people never had these employment conditions, had simply not used those provisions in the past year (e.g. taken no sick leave, or had no reason to take parental leave) or were unaware of the terms of their employment contract.

This analysis holds true both for minimum code provisions (annual holidays, sick leave, parental and bereavement 
Figure 8. Part-time as a proportion of total employment by industry in New Zealand, August 1987 and 1994

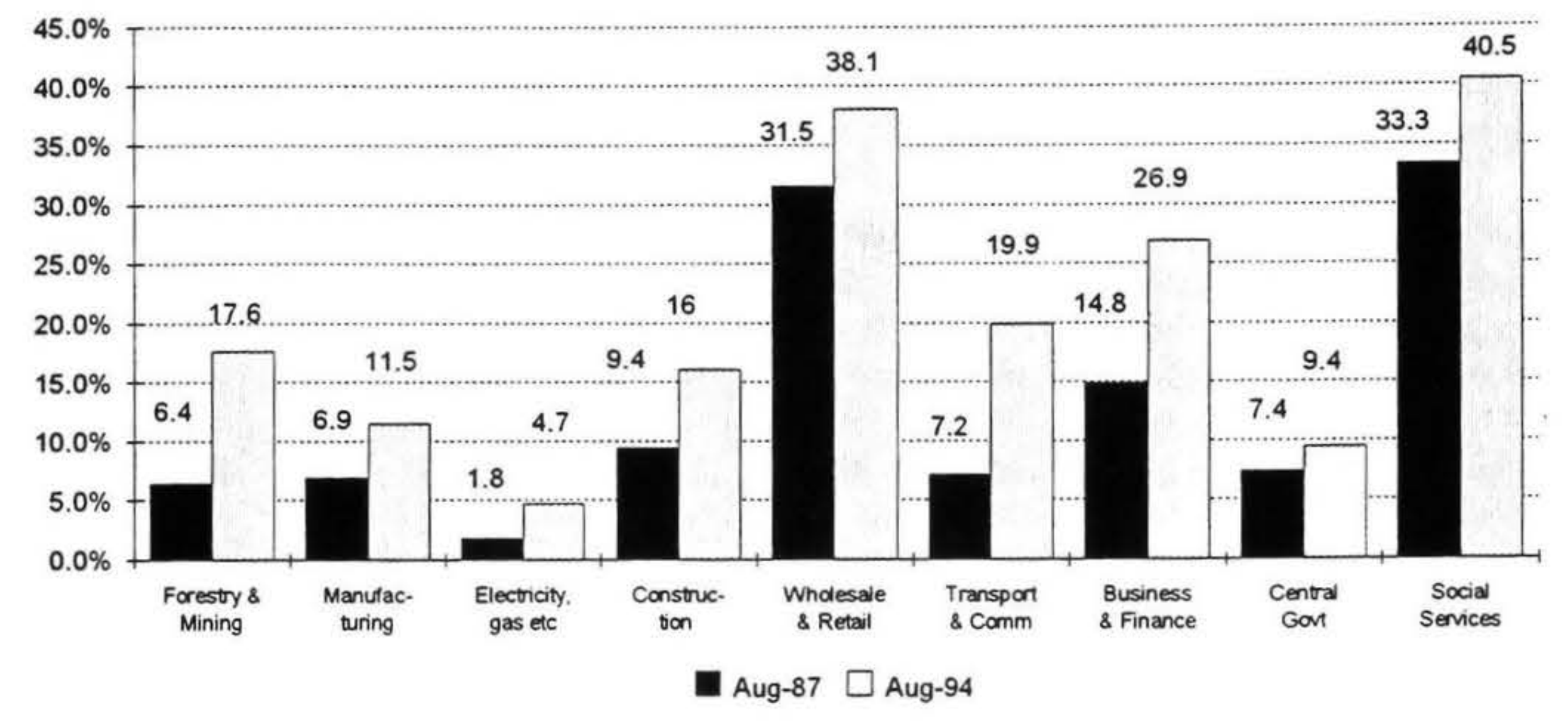

Source: Statistics New Zealand, Quarterly Employment Survey

leave) and other benefits such as child care, redundancy and superannuation provisions ${ }^{6}$. However, it is particularly marked in relation to the minimum code. For instance, over 40 per cent of casual employees answered 'never had/not applicable' in response to questions about changes to their annual and sick leave provisions. The equivalent figures for permanent employees were 2.9 per cent and 5.5 per cent for annual leave and sick leave respectively. Similarly, 22.3 per cent of part-time employees felt they were not covered by annual leave provisions, and 27.9 per cent felt that they fell outside of sick leave provisions. For fulltime employees the equivalent figures were only 2.2 per cent and 4.1 per cent.

The same survey also shows that part-time and casual employees were considerably less likely than fulltime and permanent employees to have had increases in their basic hourly rates or overall take home pay between September 1992 and August and September 1993. This trend was more pronounced than the differences between men and women, suggesting that it is women's higher concentration in part-time and casual work that reduced their likelihood of having received a pay increase. Whilst 48.6 per cent of fulltimers and 46.6 per cent of permanent workers had an increase in their overall take home pay, only 31.2 per cent of part-timers and 31.25 per cent of casual workers did so. With respect to basic hourly rates, whilst 53.2 per cent of fulltimers and 50.2 per cent of permanent workers had an increase, only 34.9 per cent of part-timers and 34 per cent of casual workers did so.

In a survey of women members of the Service Workers Union in June-July 1993 Harbridge (1993) used the same questions on employment contracts that had been used by Heylen Research in the 1992 Survey of Labour Market
Adjustment. ${ }^{7}$ The survey reports that overall take home pay had declined for about 30 per cent of the respondents. Of the 20 per cent that had an increase, most were attributable to longer hours. Forty per cent of the respondents experienced a reduction in penal and overtime rates and allowances. Around 7.5 per cent of respondents indicated that sick leave and annual leave were not applicable to them, while a little over 17 per cent indicated that bereavement leave was not applicable.

Davidson and Bray (1994) highlight factors that relate to increasing precariousness of work, particularly in the retail sector. Diminishing fulltime employment, perceptions of 'take-it-or-leave-it' contract variations were recounted in the interviews that they undertook in their research (particularly changes to hours of work at the initiative of the employer and increased casualisation of part-time employees).

\section{Conclusion}

The growth of non-standard work compared with standard employment has been significant, to the extent that the use of the term non-standard may carry an unfairly pejorative connotation for work that is now so common and important for the labour market as a whole.

This paper has explored with a very broad brush nonstandard work in New Zealand. This required a suggested definition of non-standard work, also a brief exploration of the concept of 'precariousness' was undertaken as a possible tool for the future for analysing non-standard work in New Zealand. Selected information on the development of non-standard employment in New Zealand was presented to show the broad dimensions of the changes that 
have occurred in the labour market, particularly since 1987 , and that those dimensions have continued to expand. While the information available demonstrates the scale of much of the change this paper shows there are important limitations to our knowledge of what is happening to nonstandard workers. Most information that is available over time relates to part-time employment only, this is a serious limitation where this is only one of several categories of non-standard worker.

Non-standard work is defined by what it is not. While standard work is regular, fulltime and permanent work as an employee, work under other arrangements that does not meet this criteria is non-standard. There are tremendous variations within non-standard work and it is not necessarily associated with disadvantage in the labour market, although this is often assumed. While there are associations between non-standard work and precariousness, care should be taken to recognise that the two are not inevitably the same. Precariousness may be a useful means of analysing non-standard employment in New Zealand, but more work and information is needed.

Although there has been a rapid rise in the level of nonstandard work amongst male employees, women are still much more likely to be involved in non-standard work as employees. Amongst the self-employed as well there has been a rapid rise in the number of women involved, with the number of men also rising significantly, although not so rapidly. The significance of child care roles for women is reflected in the distribution of part-time work for women around a peak at 35 years of age.

It is important to remember that non-standard work is concentrated in service industries and occupations. Employment in Social Services, Retail and Wholesale Trade, which includes Hotels and Restaurants, and Business and Financial Services provide the vast bulk of part-time employees. These industries have both in recent years and since the 1950s showed substantial increases in the number of part-time employees.

There has also been a rise in the proportion of those parttime employees who are desiring either more hours of work or a fulltime job, particularly for men, since 1987 when this was first surveyed by the HLFS. There are signs that since the beginning of 1993 that rise has peaked and could now be declining. The rise in numbers of those desiring more work since the 1987 may indicate underemployment is associated with growth in non-standard work.

Also, there is some evidence that non-standard employees are faring less well than standard employees in the negotiation of working conditions and access to or use of minimum code provisions. However, the evidence is weak or limited and there is a need for more information.

The importance of non-standard work in the labour market makes non-standard work an important issue in the devel- opment of policy. Evidence of what is happening to nonstandard workers is limited, continuing research into nonstandard work is therefore warranted.

\section{Future research}

While this paper has shown that non-standard work has dramatically increased in incidence, there is little information on the effects of that increase on a range of labour market issues. For instance, the impacts on bargaining outcomes for non-standard employees compared with standard employees is little explored and is not known in any detail, and the impacts on such aspects as the training and the health and safety status of non-standard employees in comparison with standard employees is not explored at all.

The Department of Labour has responsibility for policy in industrial relations, occupational health and safety and the provision of a free employment matching service (which is targeted at the end of the labour market where nonstandard employment is perhaps more likely). Development of sound policy advice involves a good understanding of developments in the labour market. One of the most significant developments has been the continued growth of non-standard employment, particularly in comparison with standard employees, and yet our information in relation to this large group remains limited. It must be said, however, that non-standard workers are the most difficult to locate and obtain information on, and research is therefore expensive and difficult. Research which provides statistically robust data is essential to counter the influence of anecdote in policy development. Surveys, while costly and difficult to undertake, provide the most useful information for the development of policy.

While there is some information on the part-time work force, there is little information on temporary and casual employees. It may be that these categories of employees are in a more 'precarious' position than those who are parttime employees with permanent positions; it may be that they are less likely to know about, or to seek enforcement of, their employment rights. Research in the future could usefully explore distinctions between non-standard employees as well as those that exist between standard and non-standard workers per se.

There is little or no information on the employment conditions of any non-standard group. While there is some evidence of differential treatment of standard and nonstandard employees in the negotiation of terms and conditions since the passage of the Employment Contracts Act 1991 , the information is too impressionistic to indicate the degree of differentiation that has occurred, and the 'snap shot' that it provided is now somewhat old. The actual rates of pay, hours of work, regularity of employment, leave provisions and security of employment in comparison with standardemployees, particularly over time, would provide very useful information. This could be undertaken through a case study approach or through a broad survey. 
Employment in different industries could be contrasted through case studies to show differences in the use of nonstandard employees.

While terms and conditions of employment such as pay and leave provisions are of immediate concern, in the longer term just as important are the provision of training and safe work. If differentiation with standard workers is increasing, it may be that non-standard workers will find themselves with less training and more likely to suffer injury. These consequences could in turn lead to long term labour market effects for these workers, making it increasingly harder for them to improve their position in the market. The access of non-standard employees to training, in particular, is an area where research would be of great assistance in the development of policy.

\section{References}

Anderson, G. Brosnan, P. Walsh, P., 1992a, Adapting to the Recession: Labour Force Changes and Labour Cost Reductions. In Morrison P.S. (ed.) Labour Employment and Work in New Zealand Conference Proceedings, Victoria University of Wellington: 89-97.

Anderson, G. Brosnan, P. Walsh, P., 1992b, Casualisation and externalisation of work: some dimensions of the New Zealand experience, 9th World Congress of the International Industrial Relations Association paper, Sydney.

Anderson, G. Brosnan, P. Walsh, P., 1993, Atypical work in the public and private sector in New Zealand, Divergent paths? Industrial Relations in Australia, New Zealand and the Asia Pacific Region: Proceedings of the 7th AIRAANZ Conference: 6-17.

Campbell, I., July 1994, Theorising Labour Restructuring: The Casualisation of Employment in Australia, 1983-1994 ISA Conference paper, Bielefeld: 8 and 20.

Davidson, C.and Bray, M., 1994, Women and Part-Time Work in New Zealand: 51-69.

Department of Statistics, 1993, New Zealand Social Trends (contains information on self-employment).

Haines, L., 1991, Small Business is Big Business, New Zealand Planning Council, Wellington: 5-6.

Harbridge, R., 1993, Service Workers Union Women Members Survey, Service Workers Union, Wellington.

Heylen-Department of Labour 1992, 1993 Survey of Labour Market Adjustment.
Krishnan, V., 1991, Self employment in New Zealand, The New Zealand Labour Force - March 1991 Quarter Department of Statistics.

Lewis, H., 1990a, 'Who's in the Labour Force? A Study of Labour Force Participation', Bureau of Labour Market Research Research Report No. 7, Australian Government Publishing Service, Canberra, 1985).

Lewis, H., 1990b, Part-Time Work: Trends and Issues, Australian Government Publishing Service, Canberra, p 54.

NACEW, December 1993, Te Wahine Hanga Mahi Women and Self Employment, NACEW, Wellington.

Rodgers, G. and Rodgers J., 1989, Precarious jobs in labour market regulation: The growth of atypical employment in Western Europe International Institute for Labour Studies: 5-6

Ryan, R., January 1994, unpublished report to NACEW, A Survey of Labour Market Adjustment Under the Employment Contracts Act: Gender Analysis of the Employee Survey.

\section{Notes}

${ }^{1}$ The 1993 survey is most useful as it included all employees (the 1992 survey did not include those employed where there was less than 4 employees and local and central government employees) and had a sample of 2,000 rather than 1,000 employees.

2 Telephone surveys under represent those who are most likely to be in non-standard and precarious work as these workers are less likely to have a telephone.

3 The QES data does not include the following occupational categories, some of which are likely to contain many non-standard jobs: Agriculture and agricultural contracting; hunting and trapping; fishing; seagoing work; domestic services in households; Armed forces (including civilians); owning and leasing real estate. Also, the QES measures employment in terms of the number of jobs filled, not the number of persons employed, so percentages are of total jobs rather than the total workforce.

4 There are a number of sources on Self-employment: Krishnan, V. (1991); Haines, L. (1991); Department of Statistics (1993); NACEW (1993). These are cited under the references.

5 To ensure historical continuity the numbers of selfemployed and employed in these percentages exclude those working less than 20 hours per week. 
6 The minimum code applies to all employees whether they are full-time, part-time, permanent or casual workers, apart from the following exceptions. Employees who have not worked for the same employer for more than six months are not entitled to five days special leave. All employees receive some form of holiday pay, but only those working for the same employer for more than one year are entitled to three weeks paid annual leave. Parental leave is only available to employees who have been working for the same employer for one year for at least 10 hours each week.

${ }^{7}$ There were 962 respondents (a response rate of 27 per cent), the vast majority were older women (in their thirties or older) in part-time employment, who had been in their jobs for two or more years. The occupational status of respondents was: Cleaner/housekeeper, 35 per cent; clerk, 14 per cent; other 24 per cent; and receptionists, waitresses, nurse aides, rest home assistants and bartenders all less than 10 per cent each. Hospitals and rest homes, schools and other accounted for the bulk of the industries involved (nearly 75 per cent), with food/restaurant and hotel/hospitality accounting for a further 16.5 per cent.

\section{Author}

Richard Whatman is an analyst in the Labour Market Analysis Unit of the Department of Labour, PO Box 3705, Wellington. 